\title{
Do CEO Activists Make a Difference? Evidence from a Field Experiment
}

\section{Citation}

Chatterji, Aaron K., and Michael W. Toffel. "Do CEO Activists Make a Difference? Evidence from a Field Experiment." Harvard Business School Working Paper, No. 16-100, March 2016.

\section{Permanent link}

http://nrs.harvard.edu/urn-3:HUL.InstRepos:26274858

\section{Terms of Use}

This article was downloaded from Harvard University's DASH repository, and is made available under the terms and conditions applicable to Open Access Policy Articles, as set forth at http:// nrs.harvard.edu/urn-3:HUL.InstRepos:dash.current.terms-of-use\#OAP

\section{Share Your Story}

The Harvard community has made this article openly available.

Please share how this access benefits you. Submit a story.

\section{Accessibility}




\section{Do CEO Activists Make a Difference? Evidence from a Field Experiment}

Aaron K. Chatterji

Michael W. Toffel

Working Paper 16-100 


\title{
Do CEO Activists Make a Difference? Evidence from a Field Experiment
}

\author{
Aaron K. Chatterji \\ Fuqua School of Business, Duke University \\ Michael W. Toffel \\ Harvard Business School
}

Working Paper 16-100 


\title{
Do CEO Activists Make a Difference? Evidence from a Field Experiment ${ }^{*}$
}

\author{
Aaron K. Chatterji \\ Fuqua School of Business \\ Duke University \\ 1 Towerview Drive \\ Durham, NC 27708 \\ ronnie@duke.edu \\ Michael W. Toffel \\ Harvard Business School \\ Morgan Hall 415 \\ Boston, MA 02163 \\ mtoffel@hbs.edu
}

March 1, 2016

\begin{abstract}
Several CEOs are receiving significant media attention for taking public positions on controversial social and environmental issues largely unrelated to their core business, ranging from gay marriage to climate change to gender equality. We provide the first evidence that such "CEO activism" can influence public opinion and consumer attitudes. Our field experiment examines the impact of Apple CEO Tim Cook's public statements opposing a pending religious freedom law that critics warned would allow discrimination against same-sex couples. Our results confirm the influence of issue framing on public opinion and suggest that CEOs can sway public opinion, and potentially to the same extent as prominent politicians. Moreover, Cook's CEO activism increased consumer intentions to purchase Apple products, especially among proponents of same-sex marriage.
\end{abstract}

\footnotetext{
${ }^{*}$ We would like to thank CivicScience, particularly Ross McGowan and John Dick, for their cooperation in pursuing this research project. Co-author Chatterji is an equity-compensated adviser for CivicScience. We also thank Victor Bennett and Lamar Pierce for comments on earlier drafts, Kelley Greenman and Melissa Ouellet for excellent research assistance, and the Division of Research at the Harvard Business School for financial support.
} 


\section{Do CEO Activists Make a Difference? Evidence from a Field Experiment}

\section{INTRODUCTION}

Several high-profile CEOs have recently spoken out on contentious social and environmental issues in the United States, including gay rights, race relations, and climate change. For example, a number of business leaders, most prominently Apple CEO Tim Cook, spoke out publicly against Indiana’s Religious Freedom Restoration Act (RFRA) before and immediately after it was signed into law on March 26, 2015 (Cook 2015). These and other opponents argued that the law would legalize discrimination by allowing businesses to refuse to serve lesbian, gay, bisexual, and transgender (LGBT) customers. Proponents countered that the bill was designed to protect religious liberty (Somashekhar 2015). The day after the bill became law, Cook tweeted, “Apple is open for everyone. We are deeply disappointed in Indiana's new law” (NBC News 2015). Two days later, in a Washington Post op-ed, he referred to the Indiana law when asserting, “A wave of legislation, introduced in more than two dozen states, would allow people to discriminate against their neighbors” (Cook 2015). Salesforce.com CEO Marc Benioff also spoke out, threatening to divert business away from Indiana in response to the law (Swiatek 2015). And Angie’s List CEO Bill Oesterle expressed his displeasure with RFRA by cancelling a \$40 million project to expand his company’s headquarters in Indianapolis and by suggesting he might relocate some company operations to another state (Council 2015). By the time Indiana’s governor and legislature modified the law a week later to remove the most contentious provisions, commentators were crediting the business community, and Cook in particular, as a driving force behind the opposition to and eventual revision of RFRA (Lowery 2015; Machkovech 2015). 
The public statements by Cook, Benioff, and Oesterle about RFRA are examples of “CEO activism” (Chatterji and Toffel 2015), whereby corporate leaders (mostly CEOs) speak out on social and environmental issues largely unrelated to their core businesses. There is some historical precedent for American business leaders speaking out on polarizing social and environmental issues, ranging from prohibition to capital punishment to civil rights (Chicago Daily Tribune 1927; PBS 2011; Burress 2015). At a time when the United States is undergoing rapid demographic and social change, corporate leaders are once again emerging as prominent advocates on several controversial issues, hoping to influence the debate. Lloyd Blankfein, CEO of Goldman Sachs, publicly supported gay marriage in 2012 (CBS News 2013). Sheryl Sandberg, COO of Facebook, is a frequent commentator on workplace gender equality and wrote a bestselling book on the topic (Wall Street Journal 2013). But despite this spate of CEO activism, little is known about whether it actually has the intended influence on public opinion.

Moreover, although some customers might view CEO activism favorably, others might be alienated by it, as happened when Chick-fil-A CEO Dan Cathy spoke out against gay marriage in 2012, sparking calls for boycotts of his fast-food restaurants on college campuses and leading some to question whether the company could successfully expand to the more politically liberal northeastern states (McGregor 2012; Horovitz 2014). When Howard Schultz, CEO of Starbucks, publicly urged his baristas to write "Race Together” on coffee cups in 2015 to encourage a discussion about race relations in the aftermath of several police shootings and the subsequent protests, the press largely ridiculed his efforts (Economist 2015). While prior academic work has explored the strategic implications of corporate social responsibility (e.g., Lantos 2001; McWilliams, Siegel, and Wright 2006; Flammer and Luo 2015) and how firms develop and deploy non-market strategy towards the government and other key stakeholders 
(e.g., Eesley and Lenox 2006; Mahoney, McGahan and Pitelis 2009), whether and how CEO activism affects consumer and public attitudes remains an open question.

We conducted a field experiment to investigate the effects of CEO activism on public opinion and consumer attitudes in the context of Cook's statements on Indiana's RFRA. To investigate the influence on public opinion, we deployed a set of short surveys asking respondents to indicate their support for the law. In our baseline condition, we simply asked respondents whether they supported RFRA. In another condition, we prefaced this question with an unattributed statement indicating that some were concerned that this law would allow discrimination. We ran other conditions attributing this concern to Cook, to another business leader, or to particular politicians. We crafted our research design to discern whether mentioning the discrimination concern—and who expressed it—affected public support for the law. We conducted a second set of short surveys to assess the influence of Cook's CEO activism on consumers’ intent to purchase Apple products in the near future. We primed each respondent with a statement describing Cook’s generic management philosophy, or with one describing Cook's opinion of RFRA, or with no statement at all. We then asked respondents to indicate their intent to purchase Apple products. We created these alternative versions to enable us to evaluate whether informing respondents about Cook’s opinions affected their intent to purchase Apple products and whether the content of his opinions (generic management philosophy versus CEO activism) mattered. We randomly deployed these various survey conditions amongst respondents.

We find that exposure to Cook’s statement that RFRA may allow discrimination resulted in 40 percent of respondents supporting the law, substantially less than the 50-percent support reported by respondents who were not prompted with this statement; this was a statistically significant difference. We observed similar lower levels of support, ranging from 38 percent to 
42 percent, among respondents who were presented with statements containing language identical to Cook's but attributed to another CEO or to a politician or not attributed to anyone. These results reveal that CEO activism can shape public opinion by framing the public discourse and suggest they can do so as effectively as statements by politicians or unattributed remarks. The power of framing arguments to persuade audiences has been demonstrated in other settings (Grewal, Gotlieb, and Marmorstein 1994; Lakoff 2004; Scheufele and Tewksbury 2007), but not every activist commands a large audience and receives attention. However, since the media often widely report CEO statements—especially on contentious topics—our results imply that when CEOs frame public discourse, they have the potential to shape public policy. We also find suggestive evidence that the effect of framing depends on the audience. Our subsample analysis reveals that Cook's discrimination remarks erode RFRA support among advocates of same-sex marriage, but not among opponents. By contrast, the unattributed statements of concern that RFRA would allow discrimination do erode support for the law even among same-sex-marriage opponents.

Turning to the potential influence of CEO activism on consumers, we find higher intent to purchase Apple products among respondents who were exposed to Cook's CEO activism than among those who were not. (Even if respondents in the control group were aware of Cook's advocacy through other channels, it would introduce bias against finding a difference between the groups.) We find strong evidence indicating that Cook's CEO activism, and not simply the mention of him, drives this effect. Moreover, we find that same-sex-marriage supporters drive this effect; we find no evidence that Cook's statements altered the purchase intent of same-sexmarriage opponents. These results suggest that CEO activism can serve as a signal, letting consumers know where a company leader stands on a controversial issue, potentially galvanizing 
support and generating goodwill for the company, especially among those who already support the CEO’s stance.

\section{MOTIVATION}

Firms have long pursued "non-market strategies" that aim to shape the rules of the marketplace; for example, by seeking to influence government policies on taxation, subsidies, trade, human resources, the environment, and other issues (e.g., Baron 1995; Bonardi, Holburn, and Vanden Bergh 2006; Baron 2012). CEOs are sometimes the key principals in executing nonmarket strategies, as when General Electric CEO Jeffrey Immelt has advocated that the US government adopt clean energy policies (Behr 2010) that would promote his firm's large windturbine business or when Microsoft CEO Satya Nadella lobbied Congress to change US immigration policy to allow in more high-skilled workers, the very kind his firm relies on (Romm 2014).

However, beyond the rules of the marketplace that directly affect corporate profits, there are issues that shape society more broadly and are also of concern to corporations and their leaders. For example, many companies rallied during the 1980s to defend affirmative action programs by filing amicus briefs in court cases and testifying to Congressional bodies (Kelly and Dobbin 1998). Some firms conduct ambitious programs to help underserved communities, such as Goldman Sachs’s 10,000 Women program, which provides business training to women around the world (Goldman Sachs 2016). Such programs, however, face two kinds of critique. First, the literature on “strategic CSR” (Lantos 2001; McWilliams, Siegel, and Wright 2006; Porter and Kramer 2006) argues that if these efforts are not closely aligned with the organization’s core business, their social impact will be limited. Second, these corporate initiatives suffer enduring suspicion that they are thinly veiled attempts to enhance brand equity 
and attract customers, rather than good-faith efforts to translate corporate values into social impact (e.g., Hess and Warren 2008; Karnani 2010; Lyon and Maxwell 2011).

These concerns make it challenging for companies to become "activists” for social causes. Business leaders, however, have the opportunity to speak out as individuals to try to influence social issues. We view the statements of Cook, Cathy, Schultz, Sandberg, Blankfein, and other corporate leaders as examples of this kind of activity — that is, as CEO activism— which is distinct from non-market strategy, strategic CSR, and other kinds of corporate engagement with the public sphere.

As noted, these corporate leaders are speaking out on issues that are largely unrelated to their core businesses. Although race relations, gender equality, and LGBT rights are certainly relevant to the employees of Starbucks, Facebook, and Goldman Sachs, gains in these areas are unlikely to boost those companies’ short-term operating performance. When Apple CEO Tim Cook spoke out against Indiana’s RFRA, Apple was already perceived as providing an attractive working environment for LGBT employees (Frank 2013) and the company is primarily located in California, where there was no threat of similar legislation (Berry 2014).

The debate over "corporations as activists” has clear parallels with CEO activism. When corporate leaders speak out on issues unrelated to their companies' core businesses, it is an open question whether they have much impact. Further, it is unclear whether this activism creates financial benefits - intentionally or unintentionally — for the firm. These are the two questions we seek to answer in our study.

Although numerous studies have examined corporate campaign contributions (e.g., Ansolabehere, Figueiredo, and Snyder, Jr. 2003), lobbying (e.g., Hillman, Keim, and Schuler 2004), and CSR (e.g., Margolis and Walsh 2003), we know of no research that has explored CEO activism, although one recent study exploring a related phenomenon of corporate social 
advocacy found that consumers are more likely to buy products and services from firms whose political and social stances they support (Dodd and Supa 2014). Our study focuses on the role of individual leaders and not only examines the influence of CEO activism on purchasing intent, but also compares the influence that business and political leaders' social statements have on public opinion on a given issue.

Ascribing causality from a relationship between CEO activism and particular outcomes is especially difficult using traditional empirical methods because business leaders might champion causes that are already popular or might simply add their voices to a chorus of advocates already promoting the same position. To explore these questions while overcoming such methodological challenges, we deployed a field experiment (described below)—a technique rarely used in research on business and public policy.

\section{DATA AND MEASURES}

We developed a survey to gather data on how CEO activism affects an individual's (a) views on the relevant policy issue and (b) intention to purchase the company's products. To avoid crosscontamination, we asked each subject a single question about either public policy preference or purchase intent.

\section{Policy Support}

To assess a respondent's public policy preference, we developed six versions of a question that inquired about the respondent's views on RFRA. Our treatment condition provided the following preamble and question: “Apple CEO Tim Cook recently expressed his concern about Indiana's new law about religious freedom because he believes the law may allow discrimination against gays and lesbians in that state. Do you support this law?” For this and all 
other versions of the question, the variable policy support was coded 1 for yes and 0 for no. ${ }^{1}$ To assess whether respondents' views were shaped by the particular individual to whom the statement was attributed, other respondents received a version of this question in which we replaced “Apple CEO Tim Cook” with one of the following corporate or political leaders: "Indiana-based Angie’s List CEO Bill Oesterle,” "The Republican mayor of Indianapolis,” and “The mayor of Indianapolis.” To assess whether attribution in itself shaped respondents' views, another group of respondents received the following version, which provided no attribution: "Indiana recently passed a law about religious freedom, and some believe the law may allow discrimination against gays and lesbians in that state. Do you support this law?” We asked one group of respondents a baseline version of the question that omitted the preamble about discrimination and simply asked, “Do you support Indiana’s new law protecting religious freedom?”

\section{Purchasing Intent}

We developed three versions of a question about the intention to purchase Apple products. Our treatment condition provided the same preamble described above along with a purchase-intent question: “Apple CEO Tim Cook recently expressed his concern about Indiana’s new law about religious freedom because he believes the law may allow discrimination against gays and lesbians in that state. How likely are you to buy Apple products in the near future?” For this and all other versions of this question, we asked participants to respond based on the following five-point Likert scale: "Very likely” (coded 5), "Likely” (4), "Not sure” (3), "Not likely" (2), or "Definitely not” (1). We refer to this variable as purchase intent. Other

\footnotetext{
${ }^{1}$ The survey also included a "not sure" option to avoid forcing respondents to make an arbitrary yes-or-no choice when they were unsure. We excluded those responses from our primary analysis and coded policy support as a dummy variable. As a robustness test, we recoded policy support by including "not sure" responses, which we coded with the intermediate value of 0.5 , and then conducted the policy support analysis using two-sample t-tests. The results of this alternative approach were very similar to our primary analysis.
} 
respondents faced an alternative question that provided a preamble about Cook's management philosophy: “Apple CEO Tim Cook recently said his management philosophy was to focus on people, strategy, and execution. How likely are you to buy Apple products in the near future?” A different set of respondents faced our control condition, which omitted any preamble and simply asked about purchase intent: “How likely are you to buy Apple products in the near future?”

\section{Survey Implementation}

We worked with market research firm CivicScience to gather data on our survey questions. CivicScience collects over 300,000 survey responses each day via several hundred third-party websites such as newspaper websites, television and radio station websites, and entertainment websites (Pierce, Rogers, and Snyder 2015). CivicScience conducts surveys presented as a series of three questions. The first question is meant to attract the user's attention. These “engagement questions” typically ask about current events or other topics relevant to the website on which the survey is being conducted. The second question, most important for market research, is a "value question" that clients typically pay CivicScience to ask, such as "What are the most important features you will look for in buying your next smartphone?” The survey questions we developed were positioned as value questions. The third question is a "profile question” that asks for a demographic characteristic such as gender, age bracket, income bracket, or a psychographic trait. As described below, our analysis used data from one profile question: “Do you support or oppose the legalization of same-sex marriage in your state?” CivicScience maintains lists of these engagement, survey, and demographic questions and draws from each list at random so that the three questions it poses to any given user are the result of three random draws. ${ }^{2}$ CivicScience accumulates information about individuals who respond to several of its surveys if their web browsers have cookies enabled. This process enabled us to obtain

\footnotetext{
${ }^{2}$ On some sites, four questions are asked, with an additional value or profile question added to the survey.
} 
CivicScience data on multiple demographic variables for those individuals who had previously answered CivicScience surveys before ours was deployed.

CivicScience began administering our survey on April 2, 2015, the day Indiana’s governor signed the revised version of RFRA. We asked the firm to gather data for two weeks, ceasing on April 15. Sample sizes for each condition are reported in the tables.

\section{ANALYSIS AND RESULTS}

\section{Policy Support}

To analyze whether CEO activism influenced public support for RFRA, we conducted several two-sample tests of proportions that assess whether the average level of policy support differed amongst the groups of respondents who received our alternative questions. ${ }^{3}$ Table 1 reports mean levels of policy support along with 95 percent Agresti-Coull binomial confidence intervals ${ }^{4}$ and the results of the two-sample tests of proportions. Compared to the 50 percent policy support among respondents to the unframed question, the 40.2 percent policy support among respondents to the question following Tim Cook’s discrimination framing was statistically significantly less $(z=3.29, \mathrm{p}<0.01)$. Additional results in Table 1 indicate indistinguishable policy support levels across all discrimination framing conditions, whether the discrimination concern was attributed to Cook, Angie’s List CEO Bill Oesterle, the Republican mayor of Indianapolis, or just the mayor of Indianapolis — or was not attributed to anyone in particular. These results indicate that the discrimination framing, irrespective of which of these individuals did the framing — or even whether the framed statement was not attributed to anyone

\footnotetext{
${ }^{3}$ We test the difference between two proportions for two samples (1 and 2) using prtest in Stata version 13.1, using the following test statistic:

$z=\frac{\left(\hat{p}_{1-} \hat{p}_{2}\right)}{\sqrt{\hat{p}_{p} \hat{q}_{p}\left(\frac{1}{n 1}+\frac{1}{n 2}\right)}}$, where $\hat{q}=1-\hat{p}, \hat{p}_{p}=\frac{x_{1}+x_{2}}{n_{1}+n_{2}}$, where $\mathrm{n}_{\mathrm{i}}$ is the total number of respondents in sample $i$ who responded yes or no and $x_{i}$ is the number of respondents in sample $i$ who responded yes.

4 Agresti-Coull binomial confidence intervals are suitable for dichotomous variables and are recommended by Brown, Cai, and DasGupta (2001).
} 
at all—drove the decrease in public support. These results also suggest that CEOs and politicians have commensurate ability to influence the public debate by framing issues in a particular manner. Figure 1 depicts policy support levels associated with three of our conditions: unframed, the Cook discrimination framing, and the unattributed discrimination framing.

To explore potential heterogeneity in how public opinion might be swayed by CEO activism, we explored whether and how policy support differed between respondents who indicated support or opposition in response to the following question: "Do you support or oppose the legalization of same-sex marriage in your state?” Table 2 reports these results. Among supporters of same-sex-marriage legalization, the RFRA garnered only 14.3 percent policy support from those responding to the unframed question, which fell significantly to zero support from those responding to the question framed by Cook as discrimination $(\mathrm{z}=2.32, \mathrm{p}=0.02)$. This unanimous opposition associated with the Cook discrimination framing condition represents significantly less backing than the 8.3 percent policy support exhibited by the group primed with the unattributed discrimination statement $(\mathrm{z}=-1.74, \mathrm{p}=0.08)$. Although these results are based on small samples (approximately 30 respondents per cell), they suggest that, in some circumstances, CEO activism can be more persuasive than unattributed messages.

We find contrasting results among opponents of same-sex-marriage legalization, who were overall much more supportive of RFRA with policy support averaging 91.7 percent for those responding to the unframed question and a nearly identical 90.0 percent for those responding to the question framed by Cook’s statement. Interestingly, policy support was a much lower 70.2 percent among same-sex-marriage opponents who responded to the question primed by the unattributed discrimination framing, significantly less than the support among those primed by the identical discrimination statement but attributed to $\operatorname{Cook}(\mathrm{z}=2.53, \mathrm{p}=0.01)$. That same-sex-marriage opponents were more persuaded by the unattributed message than by the 
same message attributed to Cook reveals that CEO activism can sometimes be counterproductive and that CEOs wishing to persuade some groups might be more effective funding unattributed messages rather than speaking out themselves. Together, these heterogeneous results suggest that the influence of CEO activism depends on the audience. In this case, Cook may be more credible and persuasive to same-sex-marriage supporters-especially given his public statement in 2014 that he is gay - than he is to same-sex-marriage opponents.

\section{Purchasing Intent}

To analyze the effects of CEO activism on consumers' intent to purchase the company’s products, we conducted a series of two-sample t-tests comparing groups of survey respondents. Table 3 reports these results. Purchase intent averaged 2.70 among respondents who answered the unframed question and 3.02—significantly higher $(\mathrm{t}=-4.42, \mathrm{p}<0.01)$-among those primed with Cook’s discrimination framing. Priming respondents with Cook’s business philosophy resulted in an average purchase intent of 2.87, also significantly higher than that of respondents to the unframed question $(\mathrm{t}=-2.46, \mathrm{p}=0.01)$, but significantly lower than the 3.02 average for those primed by the Cook discrimination framing $(t=-2.08, p=0.04)$. Together, these results indicate that merely mentioning Tim Cook increased consumers' intention to purchase Apple products and that Cook’s CEO activism increased it further. Figure 2 illustrates purchaseintention levels associated with the unframed condition, the Cook discrimination framing, and the Cook business-philosophy framing.

Table 4 reports how these framing effects differed between those who supported the legalization of same-sex marriage and those who opposed it. Among supporters, purchase intent averaged 2.47 for those responding to the unframed question but 3.48, significantly higher $(\mathrm{t}=$ 4.50, $\mathrm{p}<0.01$ ), for those responding to Cook’s discrimination-framed statement. Purchase intent among supporters primed by Cook’s business philosophy statement averaged 3.20, also 
significantly higher than the 2.47 average for unframed responses $(t=-3.20, p<0.01)$ and statistically indistinguishable from the 3.48 average among those primed by the Cook discrimination framing $(\mathrm{t}=-1.29, \mathrm{p}=0.20)$. In summary, for same-sex-marriage supporters, Cook’s framing bolstered purchasing intent, especially when he described RFRA as discriminatory toward gays and lesbians.

A different pattern emerged among opponents of same-sex marriage. Purchase intent averaged 2.47 for those responding to the unframed question, which was statistically indistinguishable from the 2.29 average for those primed by Cook’s discrimination statement $(\mathrm{t}=$ 1.05, $\mathrm{p}=0.30)$ and the 2.66 average for those primed by Cook's business philosophy $(\mathrm{t}=-1.21$, $\mathrm{p}=0.22$ ). Interestingly, the difference between the two Cook conditions is statistically significant $(\mathrm{t}=-2.09, \mathrm{p}=0.04)$. This indicates that when Apple products are associated with the company’s CEO, Cook’s CEO activism can backfire by eroding purchasing intent amongst those who disagree with his position. In summary, our subsample analyses suggest that CEO activists may have considerably more influence on some audiences than others and that CEO activism is a double-edged sword that can promote or erode purchasing intent, depending on the audience.

\section{DISCUSSION}

This study presents the first analysis of CEO activism, whereby corporate leaders speak out on social or environmental issues that are largely unrelated to their companies' core businesses. Using a field experiment that examines the effects of Apple CEO Tim Cook's statements opposing Indiana’s religious freedom law, we demonstrate that Cook’s views decrease public support for the law, but no more so than identical statements attributed to other business and political leaders or than an identical but unattributed statement. These results suggest that there is considerable power in how political or social issues are framed (Grewal, Gotlieb, and Marmorstein 1994; Lakoff 2004; Scheufele and Tewksbury 2007) and that corporate leaders- 
whose CEO activism often attracts media attention — can use this power to their advantage when advocating in the public domain.

Further, we find that Cook's contention that the religious freedom law legalizes discrimination against gays positively influenced consumers' intent to purchase Apple products, particularly among people who supported same-sex marriage. This finding implies that when CEOs take public stands on controversial issues, they can galvanize support for their company from those who share the same viewpoint. In this manner, CEO activism's primary effect is through signaling which side of a public debate CEOs and, by implication, their companies are on. At the same time, CEO activism risks alienating consumers who disagree with the CEO’s public stance.

Our focus on CEOs and their decisions to speak out also contributes to the literature examining how the personal preferences of C-level executives and board members influence firm behavior. While the bulk of this literature focuses on how CEO preferences affect firm strategy and performance (e.g., Hambrick and Mason 1984; Finkelstein and Hambrick 1996; Waldman and Yammarino 1999, Chen, Crossland, and Luo, 2014), our study relates more closely to the few recent articles on the role of CEO political attitudes on business decisions, which find associations between the CEO’s attitude and (a) the firm's corporate social responsibility practices (Chin, Hambrick, and Trevino 2013; Di Giuli and Kostovetsky 2014) and (b) employees' tendency to engage in activism (Briscoe, Chin, and Hambrick 2014). Our work supplements this literature by examining the influence of a CEO’s political and social attitudes on citizens’ attitudes and consumers’ purchasing intent.

These results provide some of the first insights into the phenomenon of CEO activism, but much remains unexplored. For example, our analysis focused on a single famous CEO of a world-renowned company and a single policy issue. Moreover, Cook had already announced he 
was gay in a Bloomberg Businessweek article in 2014, the year before he made his remarks about RFRA, and was the first CEO of a Fortune 500 company to do so. Given that opponents of the Indiana law were already framing it as being anti-LGBT, Cook’s statements might have been particularly influential because of his own sexual orientation (Jenni and Loewenstein 1997) and notoriety. Future work that spans multiple CEOs and multiple policy issues can shed light on the generalizability of our results.

Finally, although CEO activism can have costs as well as benefits, our results suggest that under some conditions the benefits can outweigh the costs. In our case, the increase in purchasing intent for Apple products among respondents strongly supportive of same-sex marriage occurs with no commensurate decline among those opposed to same-sex marriage. However, the benefits and costs of CEO activism will likely vary with the issue, with the nature of the corporate leader's involvement, and with the elasticity of demand for the company's products. These are all areas for future study.

We believe that CEO activism is a fertile area of inquiry and we hope that future research will investigate when such activism is more likely to arise, whether it serves as a substitute or complement to strategic CSR and non-market strategies, and what influence it has on public opinion, public policy, and the company’s various stakeholders.

\section{REFERENCES}

Ansolabehere, S., J. M. de Figueiredo, and J. M. Snyder, Jr. 2003. Why is there so little money in politics? National Bureau of Economic Research (NBER) Working Paper No. 9409.

Baron, D. P. 1995. Integrated strategy: Market and nonmarket components. California Management Review 37(2): 47-65.

Baron, D. P. 2012. Business and Its Environment. Upper Saddle River, NJ: Prentice Hall.

Behr, P. 2010. GE's Immelt says U.S. policy deadlock holds back clean energy development. New York Times, September 10.

Berry, S. 2014. As Tim Cook announces he's gay, other workplaces lack equality. SFGate, October 30. http://www.sfgate.com/opinion/openforum/article/Tim-Cook-s-announcement-he-is-gay-doesn-t-end5858861.php (accessed February 2016).

Bonardi, J.-P., G. L. F. Holburn, and R. G. Vanden Bergh. 2006. Nonmarket strategy performance: Evidence from US electric utilities. Academy of Management Journal 49(6): 1209-1228. 
Briscoe, F., M. K. Chin, and D. C. Hambrick. 2014. CEO ideology as an element of the corporate opportunity structure for social activists. Academy of Management Journal 57(6): 1786-1809.

Brown, L. D., T. T. Cai, and A. DasGupta. 2001. Interval estimation for a binomial proportion. Statistical Science 16(2): 101-117.

Burress, J. 2015. The time Coca-Cola got white elites in Atlanta to honor Martin Luther King, Jr. NPR.org. April 4. http://www.npr.org/sections/codeswitch/2015/04/04/397391510/whencorporations-take-the-lead-on-social-change (accessed February 2016).

CBS News. 2013. Goldman Sachs CEO Lloyd Blankfein: Same-sex marriage support “a business issue.” March 10. http://www.cbsnews.com/news/goldman-sachs-ceo-lloyd-blankfein-same-sex-marriagesupport-a-business-issue/ (accessed February 2016).

Chatterji, A., and M. Toffel. 2015. Starbucks' "Race Together" campaign and the upside of CEO activism. Harvard Business Review: March 24. https://hbr.org/2015/03/starbucks-race-togethercampaign-and-the-upside-of-ceo-activism (accessed February 2016).

Chen, G., C. Crossland, and S. Luo. 2014. Making the same mistake all over again: CEO overconfidence and corporate resistance to corrective feedback. Strategic Management Journal 36(10): 1513-1535.

Chicago Daily Tribune. 1927. Henry Ford on capital punishment. February 1: 10. http://archives.chicagotribune.com/1927/02/11/page/10/article/henry-ford-on-capital-punishment (accessed February 2016).

Chin, M. K., D. C. Hambrick, and L. K. Trevino. 2013. Political ideologies of CEOs: The influence of executives' values on corporate social responsibility. Administrative Science Quarterly 58(2): 197232.

Cook, T. 2015. Tim Cook: Pro-discrimination “religious freedom” laws are dangerous. Washington Post. March 29.

Council, J. 2015. For Angie's List CEO, equality stand was years in the making. IBJ.com, April 4. http://www.ibj.com/articles/52578-for-angies-list-ceo-equality-stand-was-years-in-the-making (accessed February 2016).

Di Giuli, A., and L. Kostovetsky. 2014. Are red or blue companies more likely to go green? Politics and corporate social responsibility. Journal of Financial Economics 111(1): 158-180.

Dodd, M. D., and D. W. Supa. 2014. Conceptualizing and measuring "Corporate Social Advocacy” communication: Examining the impact on corporate financial performance. Public Relations Journal 8(3): 2-23.

Economist. 2015. Starbucks and branding. March 20. http://www.economist.com/blogs/democracyinamerica/2015/03/starbucks-and-branding (accessed February 2016).

Eesley, C., and M. J. Lenox. 2006. Firm responses to secondary stakeholder action. Strategic Management Journal 27(8): 765-781.

Finkelstein, S., and D. C. Hambrick. 1996. Strategic Leadership: Top Executives and Their Effects on Organizations. Minneapolis/St. Paul, MN: South-Western College Publishing.

Flammer, C., and J. Luo. 2015. Corporate social responsibility as an employee governance tool: Evidence from a quasi-experiment. Strategic Management Journal, forthcoming.

Frank, B. H. 2013. Microsoft, Apple and other tech titans get top marks in survey of LGBT inclusion policies. Geek Wire, November 19. http://www.geekwire.com/2014/microsoft-apple-tech-titans-gettop-marks-survey-lgbt-inclusion-policies/ (accessed February 2016).

Goldman Sachs. 2016. About Us. http://www.goldmansachs.com/citizenship/10000women/about-theprogram/index.html, accessed February 2016.

Grewal, D., J. Gotlieb, and H. Marmorstein. 1994. The moderating effects of message framing and source credibility on the price-perceived risk relationship. Journal of Consumer Research 21(1): 145-153.

Hambrick, D. C., and P. A. Mason. 1984. Upper echelons: The organization as a reflection of its top managers. Academy of Management Review 9(2): 193-206.

Hess, D., and D. E. Warren. 2008. The meaning and meaningfulness of corporate social initiatives. Business and Society Review 113(2): 163-197. 
Hillman, A. J., G. D. Keim, and D. Schuler. 2004. Corporate political activity: A review and research agenda. Journal of Management 30(6): 837-857.

Horovitz, B. 2014. Chick-fil-A wings in new direction after gay flap. USA Today, April 8. http://www.usatoday.com/story/money/business/2014/04/07/chick-fil-a-fast-food-dan-cathy/7250871/ (accessed February 2016).

Jenni, K., and G. Loewenstein. 1997. Explaining the identifiable victim effect. Journal of Risk and Uncertainty 14(3): 235-257.

Karnani, A. 2010. The case against corporate social responsibility. Wall Street Journal, August 23.

Kelly, E., and F. Dobbin. 1998. How affirmative action became diversity management: Employer response to antidiscrimination law, 1961 to 1996. American Behavioral Scientist 41(7): 960-984.

Lakoff, G. 2004. Don't Think of an Elephant! Know Your Values and Frame the Debate: The Essential Guide for Progressives, Including Post-election Updates. White River Junction, VT: Chelsea Green.

Lantos, G. P. 2001. The boundaries of strategic corporate social responsibility. Journal of Consumer Marketing 18(7): 595-632.

Lowery, W. 2015. Gov. Pence signs revised Indiana religious freedom bill into law. Washington Post, April 2.

Lyon, T. P., and J. W. Maxwell. 2011. Greenwash: Corporate environmental disclosure under threat of audit. Journal of Economics \& Management Strategy 20(1): 3-41.

Machkovech, S. 2015. Tim Cook leads tech sector opposition to dangerous Indiana law. Ars Technica. March 30. http://arstechnica.com/tech-policy/2015/03/tim-cook-leads-tech-sector-opposition-againstdiscriminatory-indiana-law/ (accessed February 2016).

Mahoney, J. T., A. M. McGahan, and C. N. Pitelis. 2009. Perspective-The interdependence of private and public interests. Organization Science 20(6): 1034-1052.

Margolis, J. D., and J. P. Walsh. 2003. Misery loves companies: Rethinking social initiatives by business. Administrative Science Quarterly 48(2): 268-305.

McGregor, J. 2012. Chick-fil-A CEO Dan Cathy steps into gay-marriage debate. Washington Post, July 19.

McWilliams, A., D. S. Siegel, and P. M. Wright. 2006. Corporate social responsibility: Strategic implications. Journal of Management Studies 43(1): 1-18.

NBC News. 2015. Apple's Tim Cook and other tech CEOs blast Indiana religious freedom law. March 27. http://www.nbcnews.com/tech/tech-news/apples-tim-cook-other-tech-ceos-blast-indiana-religiousfreedom-n331736 (accessed February 2016).

PBS. 2011. Roots of prohibition. http://www.pbs.org/kenburns/prohibition/roots-of-prohibition/ (accessed January 2016).

Pierce, L., T. Rogers, and J. A. Snyder. 2015. Losing hurts: The happiness impact of partisan electoral loss. Journal of Experimental Political Science, forthcoming.

Porter, M. E., and M. R. Kramer. 2006. Strategy and society: The link between competitive advantage and corporate social responsibility. Harvard Business Review 84(12): 78-85.

Romm, T. 2014. Microsoft CEO in D.C. for immigration, patents. Politico, December 8. http://www.politico.com/story/2014/12/with-immigration-privacy-ahead-microsoft-ceo-reaches-outto-hill-113409.html (accessed February 2016).

Scheufele, D. A., and D. Tewksbury. 2007. Framing, agenda setting, and priming: The evolution of three media effects models. Journal of Communication 57(1): 9-20.

Somashekhar, S. 2015. Gay rights groups criticize Indiana religious liberties law. Washington Post, March 26.

Swiatek, J. 2015. Salesforce packed a punch in galvanizing RFRA opposition. Indianapolis Star, April 3. http://www.indystar.com/story/money/2015/04/02/salesforce-packed-punch-galvanizing-rfraopposition/70842680/ (accessed February 2016).

Waldman, D. A., and F. J. Yammarino. 1999. CEO charismatic leadership: Levels-of-management and levels-of-analysis effects. Academy of Management Review 24(2): 266-285.

Wall Street Journal. 2013. After Leaning In: Facebook's Sheryl Sandberg on making it safe to talk about gender in the workplace. June 3. 
Figure 1. Policy support after three alternative framing conditions

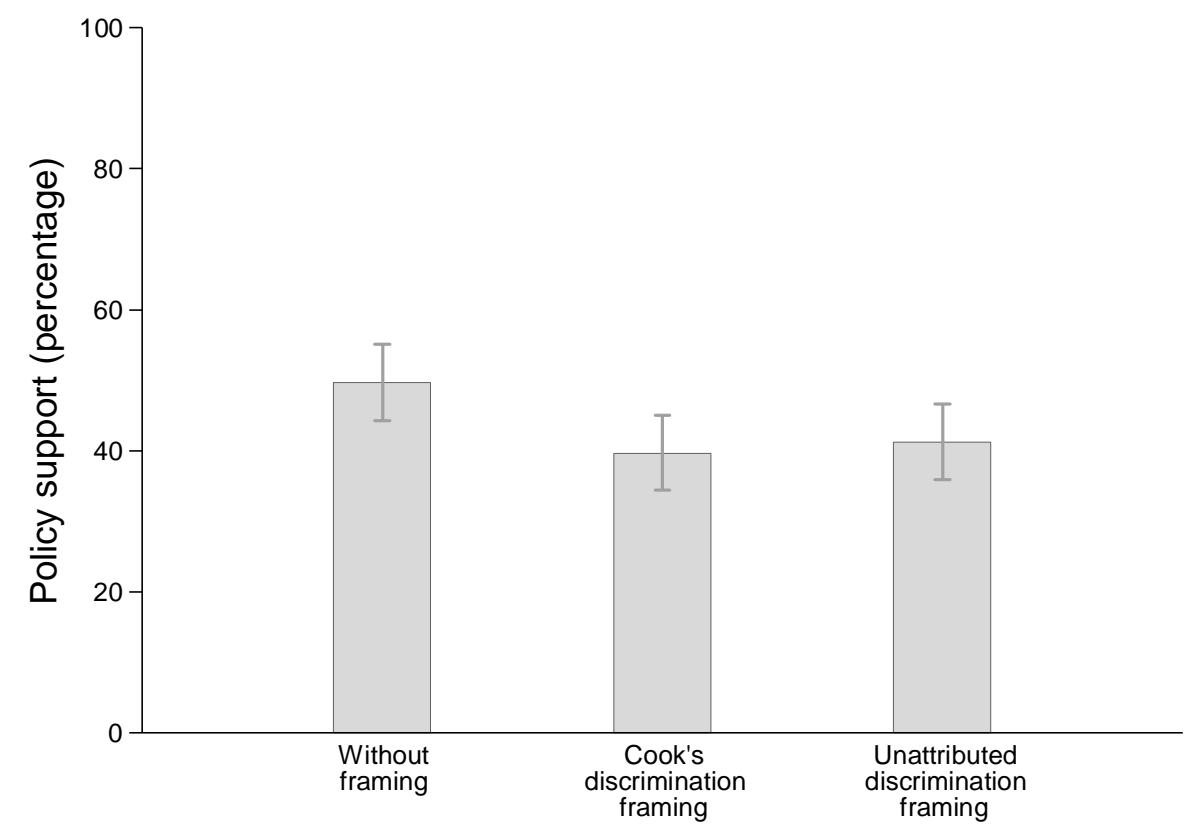

Note: This figure reports average levels of policy support after each framing condition, along with 95\% AgrestiCoull binomial confidence intervals that accommodate the dichotomous nature of this variable.

Figure 2. Intent to purchase after three alternative framing conditions

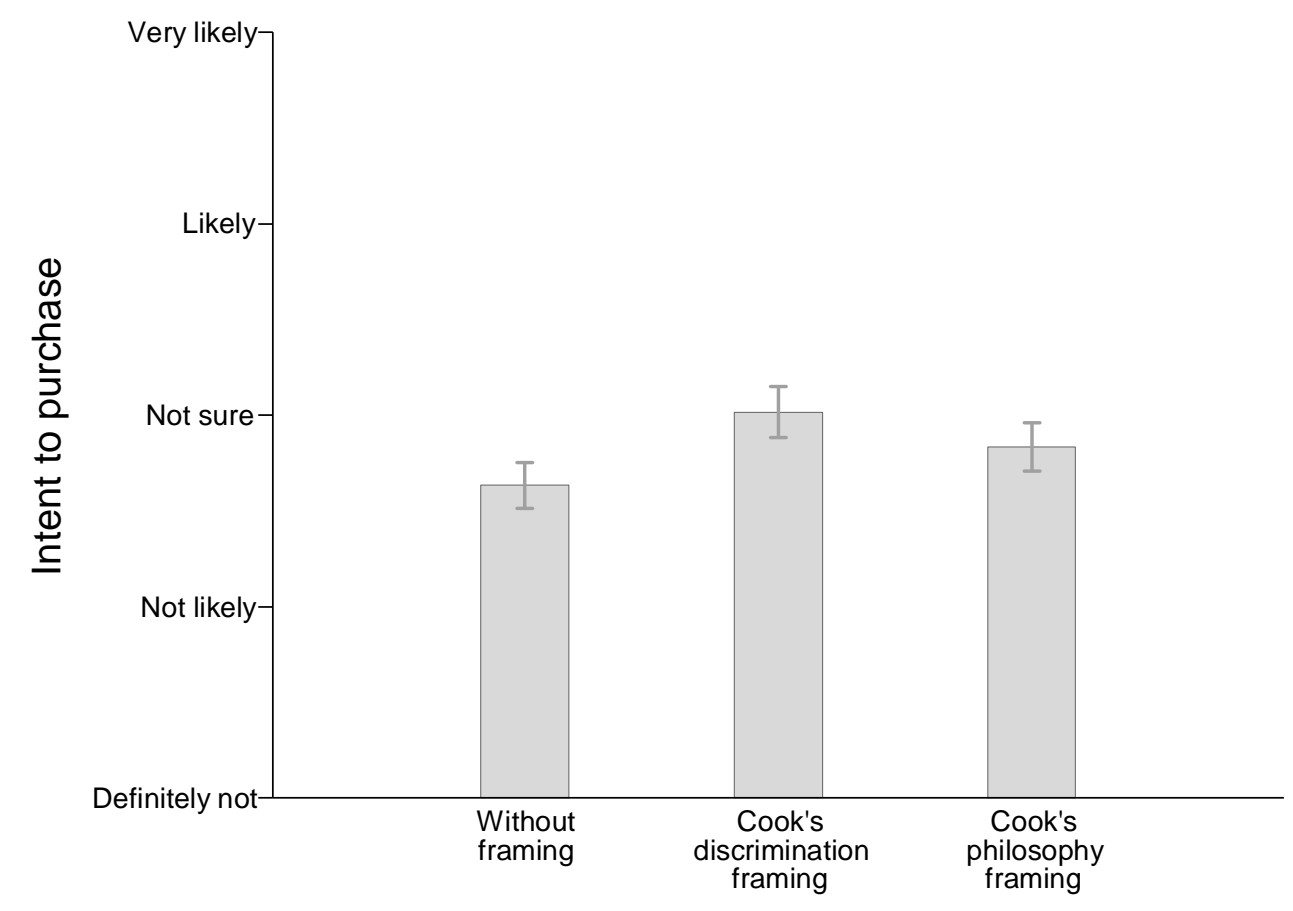

Note: This figure reports average levels of purchase intent after each framing condition, along with 95\% confidence intervals. 
Table 1. Policy support for RFRA under alternative framings

\begin{tabular}{|c|c|c|c|c|}
\hline $\begin{array}{l}\text { Framing } \\
\text { condition }\end{array}$ & Survey question & $\begin{array}{c}\text { Mean policy support, } \\
\text { [95\% confidence } \\
\text { interval], sample size } \\
\text { (N) }\end{array}$ & $\begin{array}{l}\text { Two-sample te } \\
\text { Comparison to } \\
\text { Cook condition }\end{array}$ & $\begin{array}{l}\text { of proportions } \\
\text { Comparison to } \\
\text { unattributed } \\
\text { condition }\end{array}$ \\
\hline Unframed & $\begin{array}{l}\text { Do you support Indiana's new law } \\
\text { protecting religious freedom? }\end{array}$ & $\begin{array}{c}50.0 \% \\
{[45.9-54.2 \%]} \\
N=557\end{array}$ & $\begin{array}{l}\mathrm{z}=3.29 \\
\mathrm{p}<0.01\end{array}$ & $\begin{array}{l}\mathrm{z}=3.42 \\
\mathrm{p}<0.01\end{array}$ \\
\hline Cook & $\begin{array}{l}\text { Apple CEO Tim Cook recently } \\
\text { expressed his concern about Indiana's } \\
\text { new law about religious freedom } \\
\text { because he believes the law may allow } \\
\text { discrimination against gays and lesbians } \\
\text { in that state. Do you support this law? }\end{array}$ & $\begin{array}{c}40.2 \% \\
{[36.1-44.2 \%]} \\
N=549\end{array}$ & (benchmark) & $\begin{array}{l}z=-0.11 \\
p=0.91\end{array}$ \\
\hline Oesterle & $\begin{array}{l}\text { Indiana-based Angie’s List CEO Bill } \\
\text { Oesterle recently expressed... }\end{array}$ & $\begin{array}{c}41.1 \% \\
{[37.0-45.3 \%]} \\
N=540\end{array}$ & $\begin{array}{l}z=2.88 \\
p=0.77\end{array}$ & $\begin{array}{l}z=-0.40 \\
p=0.69\end{array}$ \\
\hline Rep. Mayor & $\begin{array}{l}\text { The Republican mayor of Indianapolis } \\
\text { recently expressed... }\end{array}$ & $\begin{array}{c}41.5 \% \\
{[37.8-45.2 \%]} \\
N=687\end{array}$ & $\begin{array}{l}z=0.44 \\
p=0.66\end{array}$ & $\begin{array}{l}z=-0.56 \\
p=0.58\end{array}$ \\
\hline Mayor & $\begin{array}{l}\text { The mayor of Indianapolis recently } \\
\text { expressed... }\end{array}$ & $\begin{array}{c}37.7 \% \\
{[33.6-41.9 \%]} \\
N=519\end{array}$ & $\begin{array}{l}z=-0.84 \\
p=0.40\end{array}$ & $\begin{array}{l}\mathrm{z}=0.73 \\
\mathrm{p}=0.47\end{array}$ \\
\hline Unattributed & $\begin{array}{l}\text { Indiana recently passed a law about } \\
\text { religious freedom, and some believe the } \\
\text { law may allow discrimination against } \\
\text { gays and lesbians in that state. Do you } \\
\text { support this law? }\end{array}$ & $\begin{array}{c}39.9 \% \\
{[35.9-44.0 \%]} \\
N=566\end{array}$ & $\begin{array}{l}z=-0.11 \\
p=0.91\end{array}$ & (benchmark) \\
\hline
\end{tabular}

Note: This table reports mean levels of policy support, 95\% confidence intervals, sample size (N), and two-sample tests of proportions using prtest. Agresti-Coull binomial confidence intervals are reported to accommodate the dichotomous nature of policy support.

Table 2. Policy support under alternative framings, by respondents' opinion on legalizing same-sex marriage in their state

Framing condition

\begin{tabular}{|c|c|c|c|c|}
\hline \multirow{2}{*}{ cond } & \multirow[b]{2}{*}{$\begin{array}{c}\text { Mean policy } \\
\text { support, } \\
\text { [95\% CI], } \\
\text { N=sample size }\end{array}$} & \multirow[b]{2}{*}{$\begin{array}{c}\text { Two-sample } \\
\text { tests of } \\
\text { proportions }\end{array}$} & \multirow[b]{2}{*}{$\begin{array}{c}\text { Mean policy } \\
\text { support, } \\
{[95 \% \mathrm{CI}]} \\
\mathrm{N}=\text { sample size }\end{array}$} & \multirow[b]{2}{*}{$\begin{array}{c}\text { Two-sample } \\
\text { tests of } \\
\text { proportions }\end{array}$} \\
\hline & & & & \\
\hline Unframed & $\begin{array}{c}14.3 \% \\
{[5.8-29.9 \%]} \\
N=35\end{array}$ & $z=2.32$ & $\begin{array}{c}91.7 \% \\
{[81.5-96.8 \%]} \\
N=60\end{array}$ & $z=0.30$ \\
\hline Cook & $\begin{array}{c}0.0 \% \\
{[0.0-11.8 \%]} \\
\mathrm{N}=35\end{array}$ & $\begin{array}{l}\mathrm{p}=0.02 \\
\mathrm{z}=-1.74\end{array}$ & $\begin{array}{c}90.0 \% \\
{[78.2-96.1 \%]} \\
\mathrm{N}=50\end{array}$ & $\mathrm{p}=0.76$ \\
\hline Unattributed & $\begin{array}{c}8.3 \% \\
{[1.2-27.0 \%]} \\
N=24\end{array}$ & $p=0.08$ & $\begin{array}{c}70.2 \% \\
{[57.3-80.5 \%]} \\
N=57\end{array}$ & $\mathrm{p}=0.01$ \\
\hline
\end{tabular}

Note: This table reports mean levels of policy support, 95\% confidence intervals, sample size (N), and two-sample tests of proportions using prtest. Agresti-Coull binomial confidence intervals are reported to accommodate the dichotomous nature of policy support. 
Table 3. Intention to purchase Apple products under alternative framings

$\begin{array}{ll}\text { Framing } & \text { Framing preceding question: "How likely are } \\ \text { condition } & \text { you to buy Apple products in the near future?" }\end{array}$ condition
Mean purchase intent, [95\% CI], $\mathrm{N}=$ sample size
Two-sample t-tests

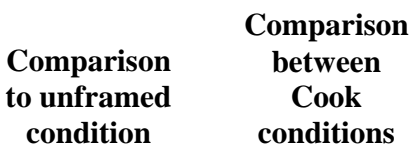

Unframed (none)

$$
\begin{gathered}
2.70 \\
{[2.60-2.80]} \\
N=738
\end{gathered}
$$

benchmark

Cook Apple CEO Tim Cook recently expressed his discrimination concern about Indiana's new law about framing religious freedom because he believes the law may allow discrimination against gays and lesbians in that state.

$$
\begin{array}{cc}
3.02 & \mathrm{t}=-4.42 \\
{[2.92-3.12]} & \mathrm{p}<0.01 \\
\mathrm{~N}=727 &
\end{array}
$$$$
\text { Apple CEO Tim Cook recently said his }
$$$$
\begin{aligned}
& \text { Cook business } \\
& \text { philosophy }
\end{aligned}
$$
management philosophy was to focus on framing people, strategy, and execution.

$\begin{array}{cc}2.87 & \mathrm{t}=-2.46 \\ 2.78-2.97] & \mathrm{p}=0.01 \\ \mathrm{~N}=711 & \end{array}$

